\title{
The importance of composite foods for estimates of vegetable and fruit intakes
}

\author{
MM O'Brien*, M Kiely, M Galvin and A Flynn \\ Department of Food and Nutritional Sciences, University College Cork, Republic of Ireland
}

Submitted 17 0ctober 2002: Accepted 1 April 2003

\begin{abstract}
Objective: To evaluate the contribution of composite foods to vegetable and fruit intakes in Irish adults and to compliance with dietary guidelines for vegetable and fruit intake.

Design: Data were analysed from the North/South Ireland Food Consumption Survey of 18-64-year-old adults ( $n=1379$; 662 men, 717 women), which used a 7-day food diary to estimate food intake.

Results: The mean intake of vegetables (excluding potatoes) was $140 \mathrm{~g} \mathrm{day}^{-1}$ (men $149 \mathrm{~g} \mathrm{day}^{-1}$; women $132 \mathrm{~g} \mathrm{day}^{-1}$ ), of fruit was $136 \mathrm{~g} \mathrm{day}^{-1}$ (men $133 \mathrm{~g} \mathrm{day}^{-1}$; women $140 \mathrm{~g} \mathrm{day}^{-1}$ ) and of potatoes was $227 \mathrm{~g} \mathrm{day}^{-1}$ (men $296 \mathrm{~g} \mathrm{day}^{-1}$; women $163 \mathrm{~g} \mathrm{day}^{-1}$ ). The mean daily intakes of vegetables, fruit and potatoes from composite foods were $37 \mathrm{~g}(26 \%), 6 \mathrm{~g}(5 \%)$ and $17 \mathrm{~g}(7 \%)$, respectively. The mean intake of vegetables from composite foods was unrelated to age or gender, but increased with increasing social class and level of education attained. The proportions of men and women meeting the recommendation for $\geq 400 \mathrm{~g} \mathrm{day}^{-1}$ ( 5 servings of $80 \mathrm{~g}$ per day) of vegetables and fruit were $21 \%$ (15\% excluding composite foods) and 19\% (12\% excluding composite foods), respectively. Compliance with the dietary recommendation decreased with decreasing levels of educational attainment and social class.

Conclusion: Intakes of vegetables and fruit are low compared with current dietary recommendations, particularly in those of lower levels of educational attainment and social class. Composite foods are an important source of vegetables (less importantly of fruit) and should be included when estimating vegetable intakes. Failure to do so may result in bias in estimates of intake and of compliance with dietary guidelines for population groups, as well as misclassification of individuals by level of intake.
\end{abstract}

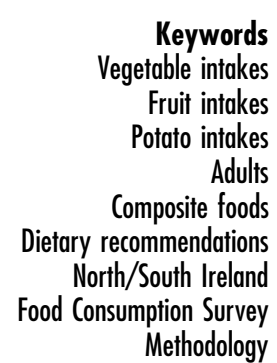

Keywords
etable intakes Fruit intakes Potato intakes Adults Composite foods North/South Ireland Methodology
Substantial epidemiological evidence exists to support the hypothesis that vegetables and fruit are protective in the aetiology of cancer ${ }^{1-5}$, coronary heart disease ${ }^{6-9}$ and other chronic diseases including stroke ${ }^{10,11}$, diabetes ${ }^{12}$ and osteoporosis $^{13,14}$. The most consistent evidence for a protective effect for vegetables and fruit against cancer has been reported for cancer of the lung, stomach and oesophagus, with less consistent but strong evidence for cancer of the oral cavity, pharynx, colon, breast, pancreas and bladder ${ }^{15}$. Raw/fresh vegetables and fruit show the strongest evidence for this protective effect, as $85 \%$ of studies have shown positive results ${ }^{16}$. Cooked vegetables and fruit have also been shown to be protective, although the body of evidence is less consistent ${ }^{15}$.

Recommendations for vegetable and fruit intakes have been made by many authorities based on epidemiological evidence showing that higher reported intakes of vegetables and fruit are inversely associated with rates of disease and death ${ }^{1,2,17-19}$.
Intakes of vegetables and fruit have been estimated in many European countries from dietary intake survey $\mathrm{data}^{20-22}$. However, the majority of studies report intakes of vegetables and fruit consumed as discrete portions only, and do not disaggregate vegetables and fruit eaten in composite foods. The importance of disaggregating composite foods in order to estimate intakes of individual foods accurately has been highlighted ${ }^{23-25}$. The estimation of total vegetable and fruit intakes requires detailed information on intakes of individual foods as well as recipe information for composite foods and dishes. Data of this type have been collected in the North/South Ireland Food Consumption Survey ${ }^{26}$, which established a database of habitual food and drink consumption in a representative sample of Irish adults, aged 18-64 years.

The objective of the present paper was to evaluate the contribution of composite foods to vegetable and fruit intakes in Irish adults and to compliance with dietary guidelines for vegetable and fruit intake. 


\section{Methods}

\section{Estimation of food and nutrient intakes}

In the North/South Ireland Food Consumption Survey ${ }^{26}$, food intake data were collected in a randomly selected representative sample of $18-64$-year-old adults ( $n=1379$; 662 men and 717 women) from the Republic of Ireland and Northern Ireland. Pregnant and lactating women were excluded $^{27}$.

A 7-day food diary was used to record food intake data. Respondents recorded each item of food and drink consumed on a separate line and each eating occasion was filled in on a separate page. A variety of different methods were used to quantify food intake ${ }^{28}$. For quantifying fruit and vegetables consumed, a hierarchical approach was used as follows:

- a photographic food atlas ${ }^{29}$ containing 70 sets of photographs depicting portion sizes of foods, developed specifically for the survey (used to quantify discrete portions of fruit and vegetables and portions of composite foods);

- a database of average weights of selected foods (e.g. fruits and vegetables obtained in supermarkets, portions of salads, takeaway food portions) compiled during the survey;

- serving sizes obtained from manufacturers' food labels; and

- food portion sizes estimated by the Ministry of Agriculture, Fisheries and Food (MAFF) ${ }^{30}$.

The food diaries were analysed using WISP $\left.{ }^{(}\right)$(Tinuviel Software, Warrington, UK), which uses the food nutrient database in McCance \& Widdowson's The Composition of Foods, fifth edition ${ }^{31}$ and supplemental volumes ${ }^{32-40}$, along with additional data (manufacturers' data, data on nutritional supplements, data on new products and recipe data) to determine nutrient intakes. All database working files were exported to SPSS ${ }^{\circledR}$ for Windows ${ }^{\mathrm{TM}}$ version 10.0 (SPSS Inc., Chicago, IL, USA) for analysis. A detailed account of the methodologies used in the survey is available $^{28}$.

\section{Estimation of vegetable and fruit intakes}

The working file used for this current analysis was derived directly from the food diary and contained a line of data for every line of information entered into the diary. Therefore, each food was listed as consumed along with its descriptors and nutrient content. A total of 3060 different food codes were recorded as having been consumed in the survey. Food codes were identified for vegetables and fruit consumed as discrete portions and as composite foods containing vegetables and fruit. The following vegetables and fruit were recorded: potatoes, peas, baked beans, other beans (including pinto beans, kidney beans, black-eye beans), lentils, carrots, lettuce, cucumber, asparagus, green beans, spinach, broccoli, Brussels sprouts, cabbage, broad beans, tomatoes, cauliflower, courgette, mushrooms, onions, peppers, parsnip, turnip, celery and leeks; and fruit juice, orange juice, bananas, oranges, other citrus fruit (including lemons, limes, mandarins), apples, pears, dried fruit (including currants, sultanas, raisins, dried apricots) and other fruit (including fruit salad, berries and melon).

For estimating vegetable and fruit intakes from composite foods, recipes and manufactured foods consumed in the survey were reviewed. Five hundred and fifty-eight recipes and 96 manufactured foods were identified as containing one or more vegetables. In addition, 118 recipes and 27 manufactured products were identified as containing one or more fruits. The contents of individual vegetables and fruits in each recipe were estimated from the recipe database compiled from information collected during the survey as well as recipe details from McCance \& Widdowson's The Composition of Foods, fifth edition ${ }^{31}$ and supplemental volumes ${ }^{32-40}$. Information obtained from manufacturers was used to estimate the contents of individual vegetables and fruits in manufactured food products. When manufacturers' information was not available, a recipe was used from McCance $\&$ Widdowson $^{31}$ and supplemental volumes ${ }^{32-40}$, the survey recipe database or popular cookery books. Vegetables and fruit in dry sauces and soups and tomato ketchup were excluded from the calculations.

The recipe and manufacturers' information detailing the contents of vegetables and fruit in composite foods was used to restructure the working SPSS file, to create three variables for each vegetable and fruit consumed: (1) weight consumed as a discrete portion, (2) weight consumed from composite foods and (3) total weight consumed (discrete portion plus composite foods). These variables were then aggregated to create total intake for categories of vegetables and fruit. This allowed estimates of vegetable and fruit intakes and compliance with dietary guidelines for vegetables and fruit to be calculated including and excluding vegetables and fruit from composite foods. Cut-off values were established separately, both including and excluding composite foods, which divided individuals into thirds of intake for vegetables, fruit, and total vegetables and fruit. The effect of excluding composite foods from estimates of intake on the classification of individuals into thirds was determined.

The impact of misreporting on estimates of vegetable and fruit intake was assessed in the current analysis by using Goldberg's cut-off of energy intake over basal metabolic rate (EI/BMR) of $<1.05^{41}$.

The mean daily intake $\left(\mathrm{g} \mathrm{day}^{-1}\right.$ and $\mathrm{g}$ per $10 \mathrm{MJ}$ food energy per day) of each vegetable/fruit group, total vegetables (excluding potatoes) and total fruit was determined for men and women by age. The mean contribution of composite foods to vegetable and fruit intakes was estimated in $\mathrm{g} \mathrm{day}^{-1}$ and as mean percentage of the total, for men and women by age and also for those 
in different categories of social class, education level attained and smoking behaviour. The average serving sizes were estimated for vegetables and fruit consumed as discrete portions and from composite foods, for men and women.

\section{Estimation of the contribution of vegetables and fruit to mutrient intakes}

The mean daily intake of individual nutrients was determined for each subject from each vegetable and fruit group, consumed as discrete portions and as components of dishes and manufactured foods. For each nutrient the percentage contribution of each vegetable and fruit group to the total intake of that nutrient was estimated. All recipes accounted for nutrient losses in cooking according to guidelines from McCance \& Widdowson $^{31}$ and supplemental volumes ${ }^{32-40}$.

\section{Statistical analysis}

Differences in mean vegetable and fruit intakes between men and women were assessed using parametric independent $t$-tests and between age groups using a parametric one-way analysis of variance (ANOVA) (using Scheffe's post-hoc test). Values of $P<0.01$ were taken as statistically significant. Differences in the percentage of consumers of vegetables and fruit between men and women were assessed using Cramers' V chi-squared test. Differences in the mean contribution (g) and (\%) were assessed with a one-way ANOVA using the post-hoc Scheffe test for values complying with Levene's homogeneity of variance $(P>0.05)$ and the Games-Howell posthoc test for those that did not comply with Levene's test $(P<0.05)$. Differences in the percentage of individuals meeting current recommendations for vegetable and fruit intake were assessed using Cramers' V chi-squared analysis. Values of $P$ for statistical significance and the test used are indicated in each table.

\section{Results}

\section{Intake of vegetables (excluding potatoes)}

All subjects consumed vegetables at least once during the 7-day period of recording (Table 1). Apart from potatoes, the most commonly consumed vegetables were onions, carrots, tomatoes and peas. The vegetable foods eaten in the largest quantities in both men and women were tomatoes and carrots (Table 1). Significantly fewer men than women consumed salad vegetables, broccoli, tomatoes and peppers, and significantly more men than women consumed beans (Table 1).

The mean daily total vegetable intake for the total population was $140 \mathrm{~g} \mathrm{day}^{-1}(170 \mathrm{~g}$ per $10 \mathrm{MJ}$ food energy per day) and intakes were significantly higher $(P<0.001)$ in men ( $\left.149 \mathrm{~g} \mathrm{day}^{-1}\right)$ than in women $\left(132 \mathrm{~g} \mathrm{day}^{-1}\right)$ (Table 1). When adjusted for energy, mean intakes were significantly higher $(P<0.001)$ in women $(188 \mathrm{~g}$ per $10 \mathrm{MJ}$ food energy per day) than in men $(150 \mathrm{~g}$ per $10 \mathrm{MJ}$ food energy per day). The 18-35 year age group had the lowest intakes of total vegetables, particularly green vegetables and peas, and the highest intakes of baked beans (Table 2). The percentage of consumers of green vegetables (broccoli and cabbage) and cauliflower increased significantly $(P<0.001)$ with age.

\section{Potato intake}

Most potatoes were consumed as mashed, boiled or baked potatoes, and chipped, fried and roasted potatoes were also consumed in substantial quantities. The mean daily intake of total potatoes was significantly higher $(P<0.001)$ in men than in women even when intakes were adjusted for food energy (Table 1 ).

Total potato consumption increased significantly $(P<0.01)$ with age. Mashed, boiled and baked potatoes were consumed in the highest quantities in the 51-64 year age group, while chipped, fried and roasted potatoes were consumed in the highest quantities in the 18-35 year age group (Table 2). The number of consumers of chipped, fried and roasted potatoes decreased significantly $(P<0.001)$ with age (Table 2$)$.

\section{Fruit intake}

Ninety per cent ( $88 \%$ of men, $92 \%$ of women) of the population consumed fruit. The fruits consumed most commonly and those consumed in the largest quantities were apples, bananas and orange juice (Table 3). The mean daily intake of fruit in the population was $136 \mathrm{~g} \mathrm{day}^{-1}$ (165 g per $10 \mathrm{MJ}$ food energy per day) (men, $133 \mathrm{~g} \mathrm{day}^{-1}$ (135g per $10 \mathrm{MJ}$ food energy per day); women, $140 \mathrm{~g} \mathrm{day}^{-1}$ (193g per $10 \mathrm{MJ}$ food energy per day)) (Table 3). Mean daily total fruit intake $\left(\mathrm{g} \mathrm{day}^{-1}\right.$ ) was not significantly different between men and women; however, when adjusted for energy, mean intakes (g per $10 \mathrm{MJ}$ food energy per day) were significantly higher $(P<0.01)$ in women than men (Table 3$)$.

Mean daily fruit consumption was lowest in the 18-35 year age group in both men $\left(113 \mathrm{~g} \mathrm{day}^{-1}\right)$ and women $\left(115 \mathrm{gday}^{-1}\right)$, and fruit intake increased with age in women. Mean daily intakes of bananas and 'other fruits' (including apples, pears and dried fruit) increased significantly $(P<0.01)$ with age (Table 4$)$. Differences between age groups in mean intakes of total fruit $\left(\mathrm{g} \mathrm{day}^{-1}\right)$ were not significant but increased significantly $(P<0.01)$ with increasing age when adjusted for food energy (Table 4).

\section{Contribution of composite foods to vegetable and fruit intake}

Table 5 shows the contribution of composite foods to the total intake of vegetables and fruit for men and women by age.

The mean intake of vegetables from composite foods was $37 \mathrm{~g} \mathrm{day}^{-1}$, which represents $26 \%$ of total vegetable 


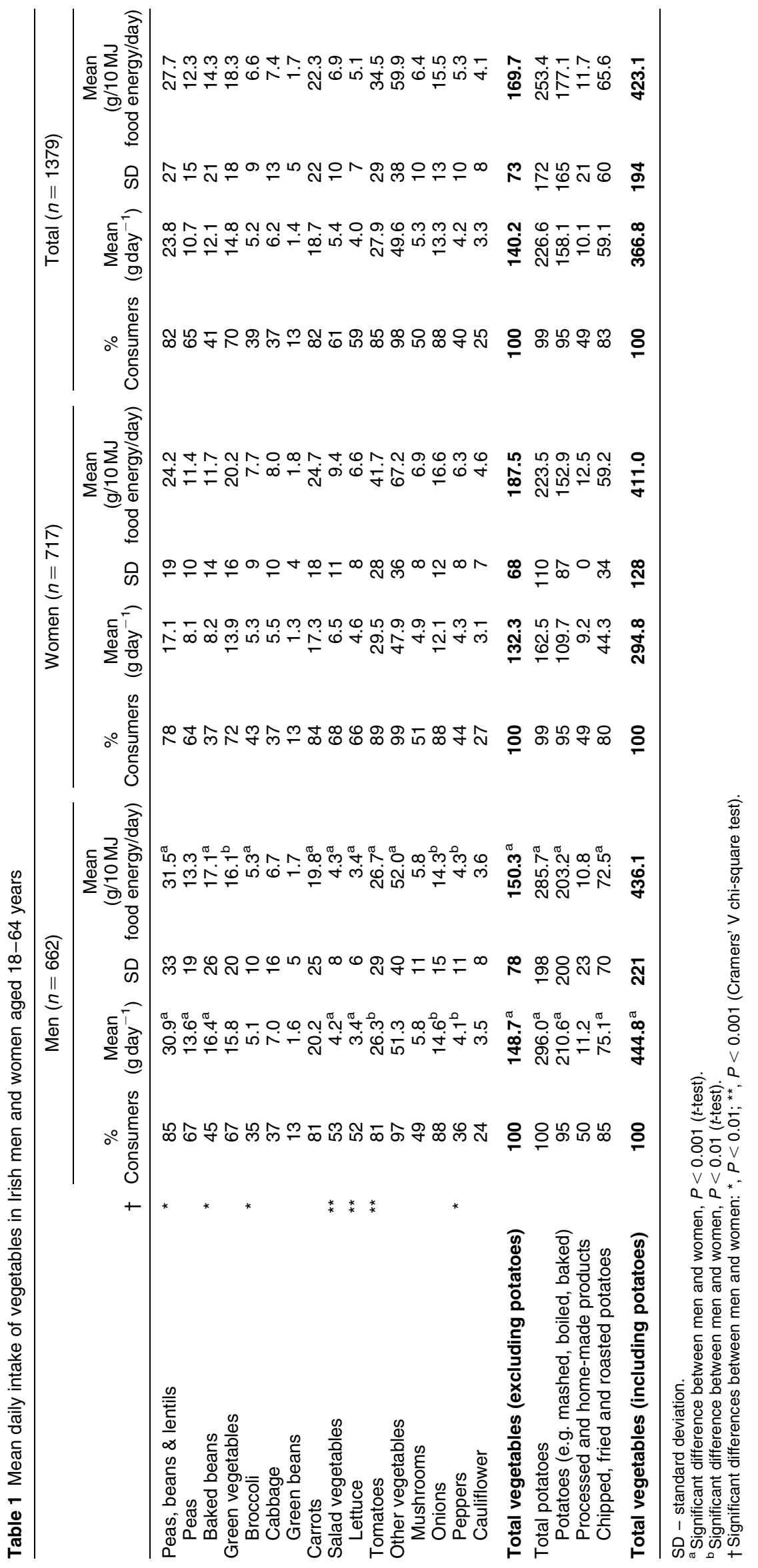




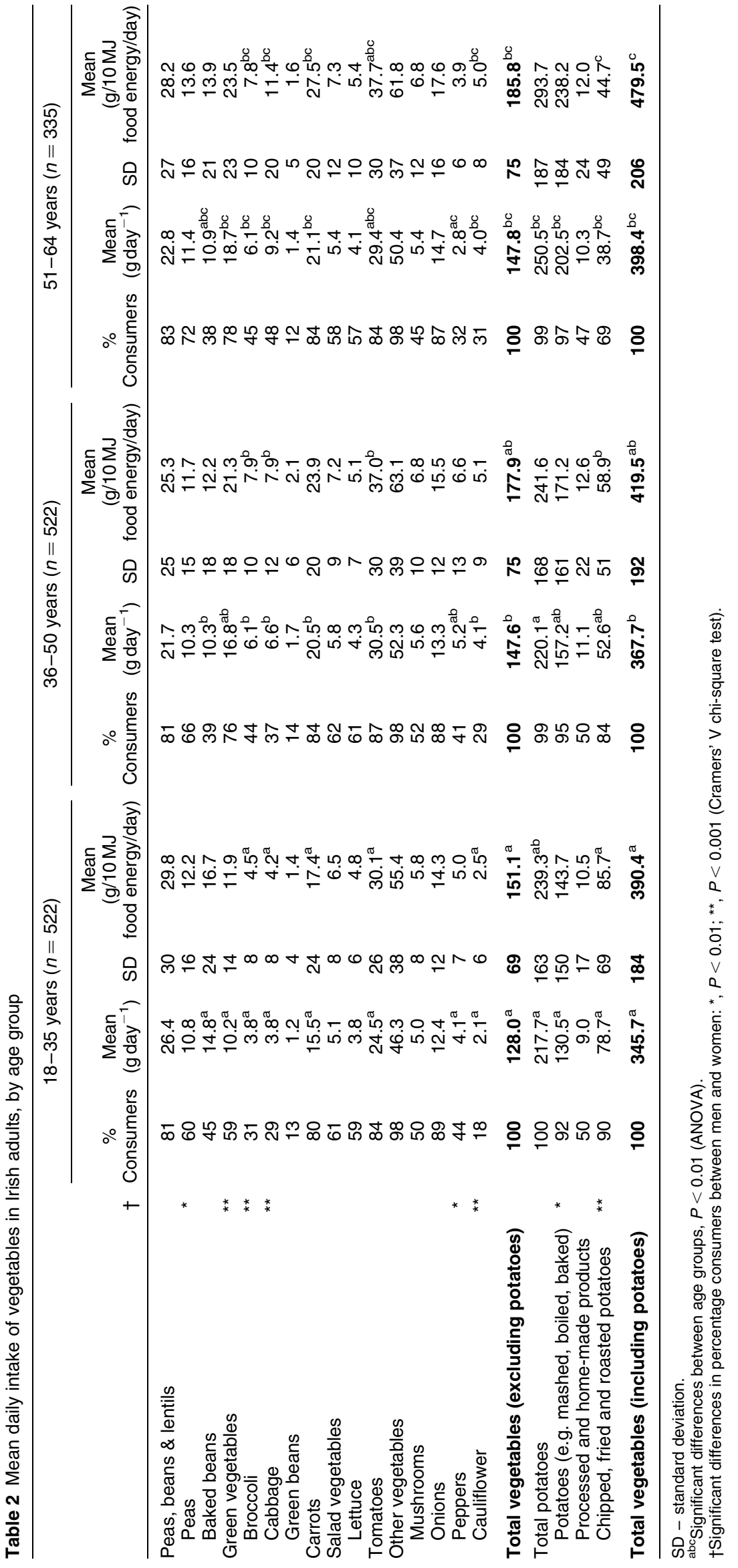



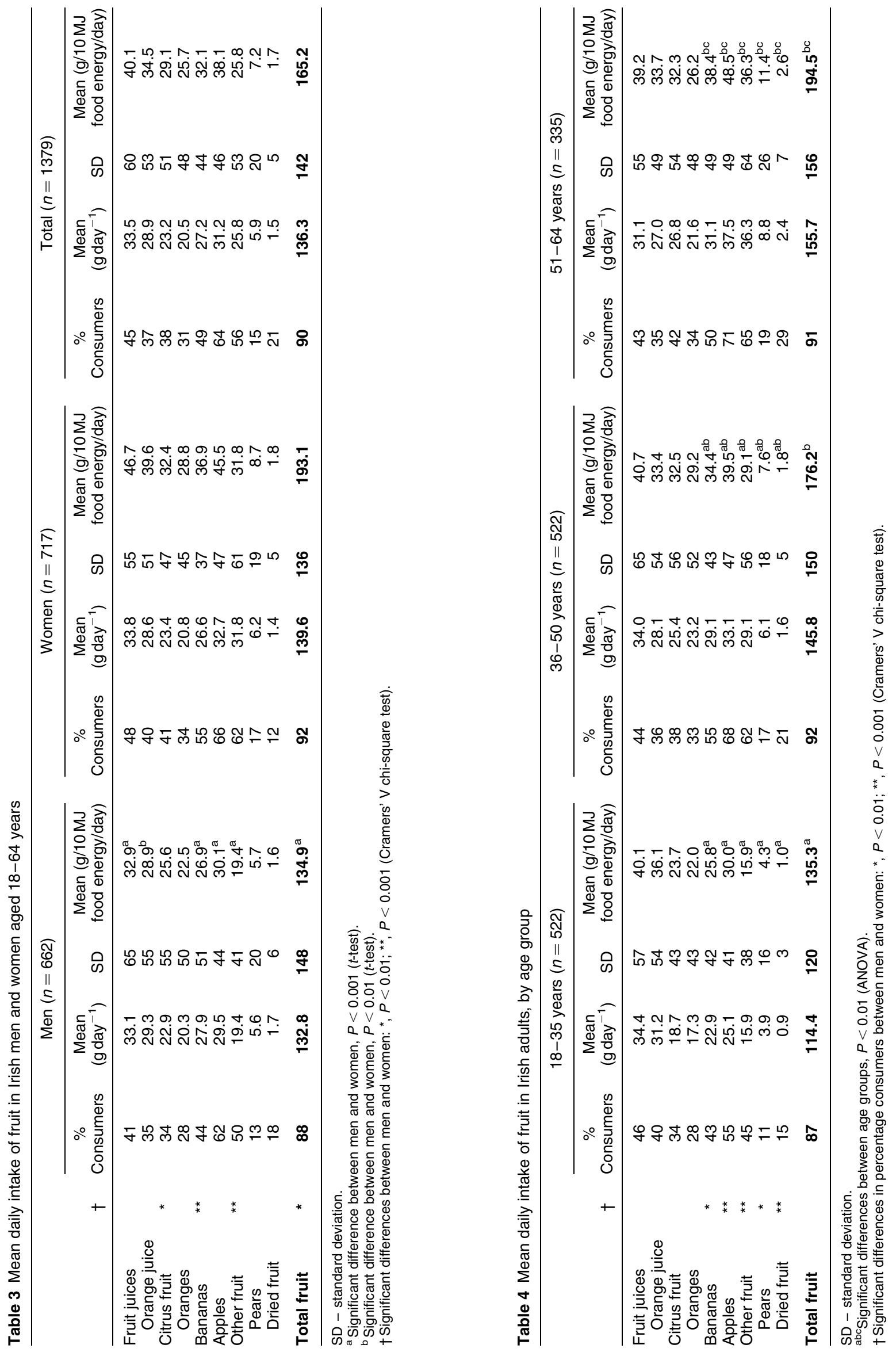


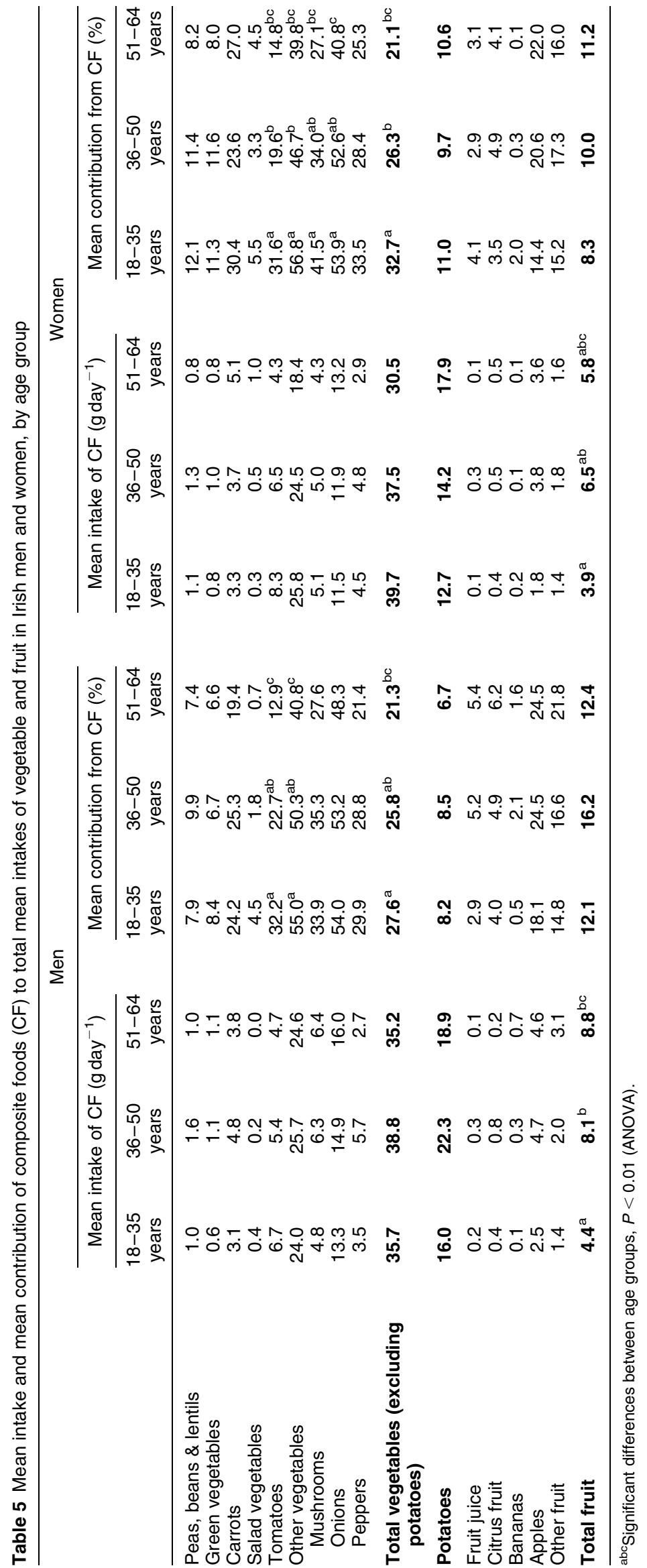


(excluding potatoes) consumption in the population. When adjusted for differences in energy intakes, mean intake of vegetables from composite foods was $44 \mathrm{~g}$ per $10 \mathrm{MJ}$ food energy per day, and was significantly lower in men ( $37 \mathrm{~g}$ per $10 \mathrm{MJ}$ food energy per day) than in women ( $50 \mathrm{~g}$ per $10 \mathrm{MJ}$ food energy per day). The average contribution of composite foods to total vegetable intake in individuals was 26\% (25\% in men and $27 \%$ in women). The largest contributions made by composite food items to individual vegetable categories were in carrots, tomatoes and the 'other vegetables' category, which includes mushrooms, onions and peppers. Over 60\% of all mushrooms, onions and peppers were consumed as part of a composite food (Table 5). The contribution of composite foods to total vegetable intake $\left(\mathrm{g} \mathrm{day}^{-1}\right)$ was similar across the age groups for men and women and decreased with age in both men and women for most vegetable categories.

For potatoes, the mean intake from composite foods was $17 \mathrm{~g} \mathrm{day}^{-1}$, which represents $7 \%$ of total potato consumption in the population, with an average contribution of composite foods to total potato intake in individuals of $9 \%$ ( $8 \%$ in men and 10\% in women). Men and women aged 18-35 years reported the largest contribution of composite foods to mean potato intakes (Table 5).

When adjusted for differences in energy intakes, mean intake of potatoes from composite foods was $19 \mathrm{~g}$ per $10 \mathrm{MJ}$ food energy per day (men, $18 \mathrm{~g}$ per $10 \mathrm{MJ}$ food energy per day; women, $19 \mathrm{~g}$ per $10 \mathrm{MJ}$ food energy per day).

The mean intake of fruit from composite foods was $6 \mathrm{~g}$ or $5 \%$ of total fruit consumption in the population. When adjusted for differences in energy intakes, mean intake of fruit was $7 \mathrm{~g}$ per $10 \mathrm{MJ}$ food energy per day (men, $6 \mathrm{~g}$ per $10 \mathrm{MJ}$ food energy per day; women, $7 \mathrm{~g}$ per $10 \mathrm{MJ}$ food energy per day). The average contribution of composite foods to total fruit intake in individuals was 12\% (14\% in men and $10 \%$ in women). The contribution of composite foods to total fruit intake $\left(\mathrm{g} \mathrm{day}^{-1}\right)$ was significantly different $(P<0.01)$ across the age groups for men and women (Table 5).

For mean daily intakes of vegetables (excluding potatoes), the 5th percentile (P5) and 95th percentile (P95) from composite foods were 0 and $106 \mathrm{~g}$, respectively; for fruit, P5 and P95 from composite foods were 0 and $27 \mathrm{~g}$, respectively; and for potatoes, P5 and P95 from composite foods were 0 and $257 \mathrm{~g}$, respectively.

Mean intakes $\left(\mathrm{g} \mathrm{day}^{-1}\right)$ of vegetables from composite foods were not significantly different for men and women in different age groups. Professional, managerial and technical workers consumed more vegetables in composite foods than semi-skilled and unskilled workers. Individuals educated to tertiary level also consumed significantly more vegetables as a component of composite foods than those educated to primary and secondary level (Table 6).

Table 6 Mean intake of vegetables, fruit, and total vegetables and fruit from composite foods (CF) in Irish men and women in different age groups and for different categories of social class, education level attained and smoking habits

\begin{tabular}{|c|c|c|c|}
\hline & \multicolumn{3}{|c|}{ Mean intake from CF $\left(\right.$ g day $\left.^{-1}\right)$} \\
\hline & Total vegetables & Total fruit & $\begin{array}{c}\text { Total vegetables } \\
\text { and fruit }\end{array}$ \\
\hline \multicolumn{4}{|l|}{ Men } \\
\hline $18-35$ years & 35.7 & $4.5^{\mathrm{a}}$ & 40.2 \\
\hline $36-50$ years & 38.8 & $8.1^{\mathrm{b}}$ & 47.0 \\
\hline $51-64$ years & 35.2 & $8.7^{\mathrm{bc}}$ & 43.9 \\
\hline Total & 36.7 & 6.9 & 43.6 \\
\hline \multicolumn{4}{|l|}{ Women } \\
\hline $18-35$ years & 39.7 & $3.9^{\mathrm{a}}$ & 43.6 \\
\hline $36-50$ years & 37.5 & $6.5^{\mathrm{b}}$ & 43.9 \\
\hline $51-64$ years & 30.5 & $5.8^{\mathrm{abc}}$ & 36.3 \\
\hline Total & 36.7 & 5.4 & 42.1 \\
\hline \multicolumn{4}{|l|}{ Social class } \\
\hline Professional, managerial \& technical & $41.9^{\mathrm{a}}$ & 7.3 & $49.2^{\mathrm{a}}$ \\
\hline Non-manual \& skilled manual & $37.3^{\mathrm{ab}}$ & 5.3 & $42.6^{\mathrm{ab}}$ \\
\hline Semi-skilled \& unskilled manual & $31.8^{\mathrm{bc}}$ & 5.4 & $37.3^{\mathrm{bc}}$ \\
\hline Unskilled & $30.8^{\mathrm{bcd}}$ & 4.8 & $35.6^{\mathrm{bcd}}$ \\
\hline \multicolumn{4}{|l|}{ Education level attained } \\
\hline Primary & $26.2^{\mathrm{a}}$ & 5.7 & $31.9^{\mathrm{a}}$ \\
\hline Intermediate & $30.2^{\mathrm{ab}}$ & 5.4 & $35.6^{\mathrm{ab}}$ \\
\hline Secondary & $38.1^{\mathrm{bc}}$ & 7.0 & $45.2^{\mathrm{bc}}$ \\
\hline Tertiary & $45.9^{\mathrm{cd}}$ & 6.3 & $52.2^{\mathrm{cd}}$ \\
\hline \multicolumn{4}{|l|}{ Smoking habits } \\
\hline Current smoker & 34.5 & 5.2 & 39.7 \\
\hline Ex-smoker & 39.2 & 6.9 & 46.1 \\
\hline Non-smoker & 37.3 & 6.2 & 43.5 \\
\hline
\end{tabular}

${ }^{\text {abcd }}$ Significant differences in mean intakes across categories, $P<0.01$ (ANOVA).

No significant differences between men and women. 
Fruit intake from composite foods was lowest in men and women aged $18-35$ years (Table 6). Intakes of fruit from composite foods were not significantly different between categories of social class and education level attained or in those with different smoking habits (Table 6).

\section{Estimation of average serving size}

Mean serving size of vegetables and fruit consumed as discrete portions was significantly higher $(P<0.001)$ in men than women (Table 7). Average serving sizes of vegetables and fruit consumed as a component of a composite food were not significantly different. However, the high P95 for vegetables indicates that some individuals consume quite large amounts of vegetables from composite foods (Table 7).

\section{Misclassification into thirds of mean intake}

Figures 13 show the impact of excluding composite foods from estimates of intake on the classification of individuals into thirds of intake for vegetables, fruit, and total vegetables and fruit combined.

Excluding composite foods from estimates of mean vegetable intakes resulted in misclassification across all three tertiles of intake, with the lowest and the highest tertile of intake being misclassified by between 23 and $26 \%$ (Fig. 1). Excluding composite foods from estimates of mean fruit intakes misclassified $27 \%$ of men and $14 \%$ of women as non-consumers, while $18 \%$ of men and $9 \%$

Table 7 Mean serving size of vegetables and fruit consumed as discrete portions and as a portion from composite foods

\begin{tabular}{|c|c|c|c|}
\hline & \multicolumn{3}{|c|}{ Mean serving size $(\mathrm{g})$} \\
\hline & Men $(n=662)$ & Women $(n=717)$ & All $(n=1379)$ \\
\hline \multicolumn{4}{|c|}{ Vegetables } \\
\hline \multicolumn{4}{|c|}{ Discrete portion } \\
\hline Mean & $113.1^{\mathrm{a}}$ & 97.2 & 104.9 \\
\hline SD & 46.1 & 36.9 & 42.3 \\
\hline P5 & 51.8 & 47.2 & 49.1 \\
\hline P95 & 196.4 & 165.9 & 182.5 \\
\hline \multicolumn{4}{|c|}{ Composite foods } \\
\hline Mean & 78.3 & 71.9 & 74.9 \\
\hline SD & 59.2 & 55.8 & 57.5 \\
\hline P5 & 11.4 & 7.2 & 9.2 \\
\hline P95 & 192.7 & 165.6 & 172.9 \\
\hline \multicolumn{4}{|c|}{ Fruit } \\
\hline \multicolumn{4}{|c|}{ Discrete portion } \\
\hline Mean & $179.7^{\mathrm{a}}$ & 159.3 & 168.6 \\
\hline SD & 78.5 & 68.3 & 73.8 \\
\hline P5 & 75.9 & 72.1 & 73.1 \\
\hline P95 & 331.1 & 298.9 & 310.2 \\
\hline \multicolumn{4}{|c|}{ Composite foods } \\
\hline Mean & 41.7 & 35.7 & 38.6 \\
\hline SD & 33.1 & 37.8 & 35.7 \\
\hline P5 & 8.9 & 3.3 & 5.6 \\
\hline P95 & 92.7 & 83.9 & 91.1 \\
\hline
\end{tabular}

SD - standard deviation; P5 - 5th percentile; P95 - 95th percentile.

a Significantly different from women, $P<0.001$ ( $t$-test). of women low consumers were misclassified into the second third of intake and $9 \%$ of men and $4 \%$ of women were misclassified as high consumers (Fig. 2). Classification of individuals based on estimates of total vegetable and fruit intake resulted in misclassification of low and high consumers by between 8 and 10\% (Fig. 3).

\section{Compliance with dietary recommendations for vegetables and fruit}

Table 8 reports the effect of excluding composite foods on estimates of the percentage of different population groups achieving current dietary recommendations for vegetable and fruit intake. Approximately 21\% of men (15\% excluding composite foods) and $\sim 19 \%$ ( $13 \%$ excluding composite foods) of women achieved current dietary recommendations for vegetable and fruit intakes of $\geq 400 \mathrm{~g} \mathrm{day}^{-1}$ ( 5 or more servings of $80 \mathrm{~g}$ each) (Table 8 ).

Recommendations from the US Department of Agriculture of 3 servings of vegetables a day were achieved by $10 \%$ (4.5\% excluding composite foods) of men and $\sim 6 \%$ (2\% excluding composite foods) of women, while recommendations for 2 servings of fruit a day were achieved by $31 \%$ (30\% excluding composite foods) of men and $\sim 33 \%$ (31\% excluding composite foods) of women (Table 8).

The percentage of individuals achieving dietary recommendations for fruit and vegetables increased with increasing social class and increasing level of education (Table 8). Current smokers had the lowest level of compliance with current dietary recommendations for vegetable and fruit intake (Table 8). When composite foods were excluded the trends remained the same.

\section{Contribution of vegetables and fruit to nutrients}

The contribution of vegetables to nutrient intakes was similar for men and women. Vegetables (excluding potatoes) contributed $<3 \%$ to total energy intake but contributed $\sim 17 \%$ to dietary fibre (Southgate), $63 \%$ of carotene, $32 \%$ of total vitamin A, $13 \%$ of vitamin $\mathrm{E}$ and $11 \%$ of folate (Table 9).

Peas, beans and lentils made the largest contribution to dietary fibre intakes ( $40 \%$ of the dietary fibre from vegetables) for both men and women. Carrots were the main contributor of carotene while $40 \%$ of the vitamin C from vegetables came from 'other vegetables' (including mushrooms, peppers and onions).

The contribution of potatoes to all nutrients was slightly higher in men than in women owing to the higher quantities of potatoes consumed by men. Potatoes contributed $\sim 12 \%$ of total energy intakes and made a significant contribution to the mean daily intakes of total carbohydrate, starch, dietary fibre (Southgate), potassium, copper, magnesium, iron, vitamins $\mathrm{C}, \mathrm{E}$ and $\mathrm{B}_{6}$, folate, thiamin and pantothenate (Table 9).

Mashed, boiled and baked potatoes were the main contributors to vitamin C, total folate and fibre from total 


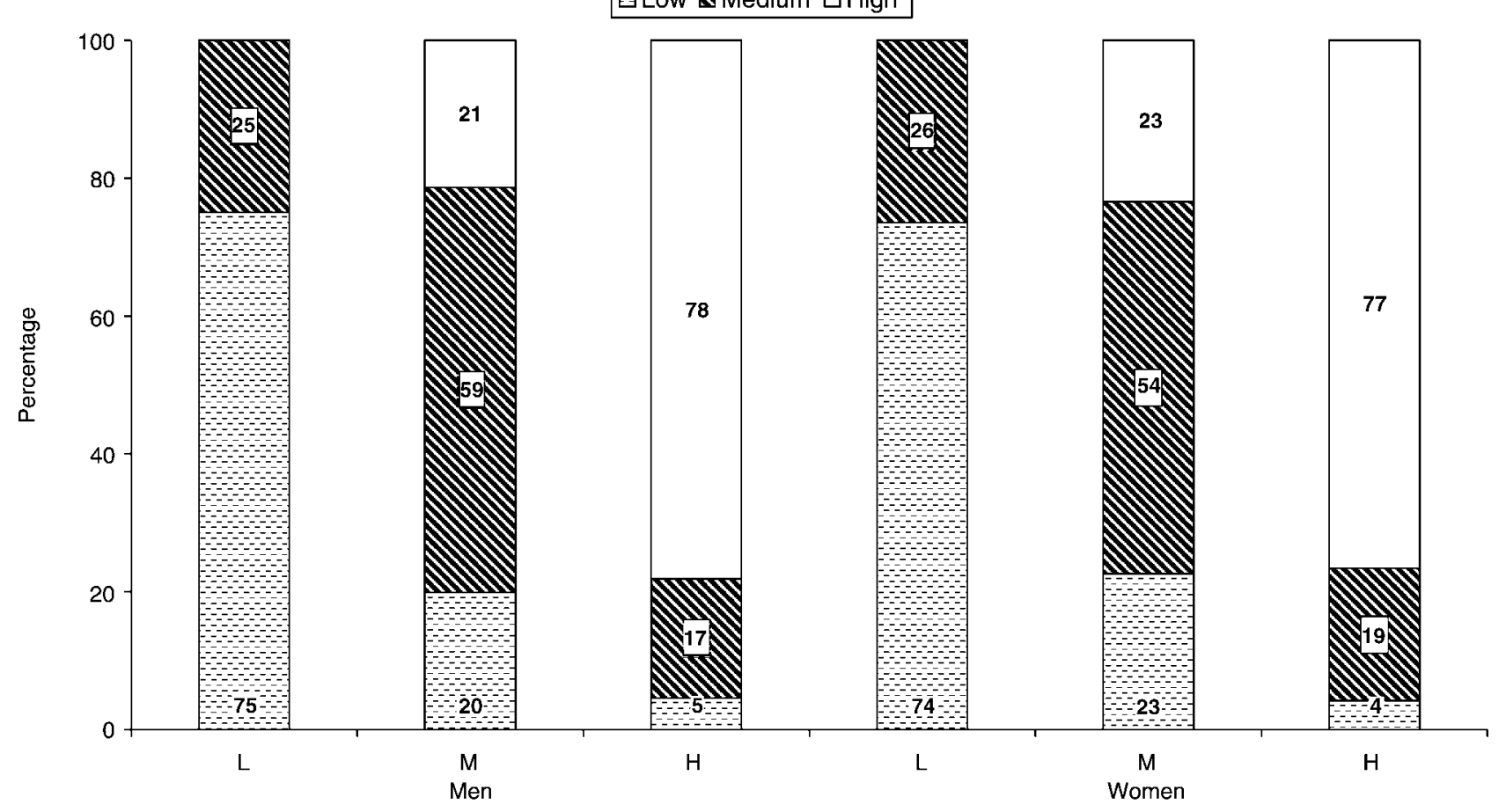

Classification of individuals as low, medium and high consumers of vegetables including composite foods in estimates of intake

Fig. 1 Percentage of individuals misclassified as low, medium and high consumers of vegetables if composite foods are excluded from estimates of intake

GLow \$Medium $\square$ High 目Non consumers

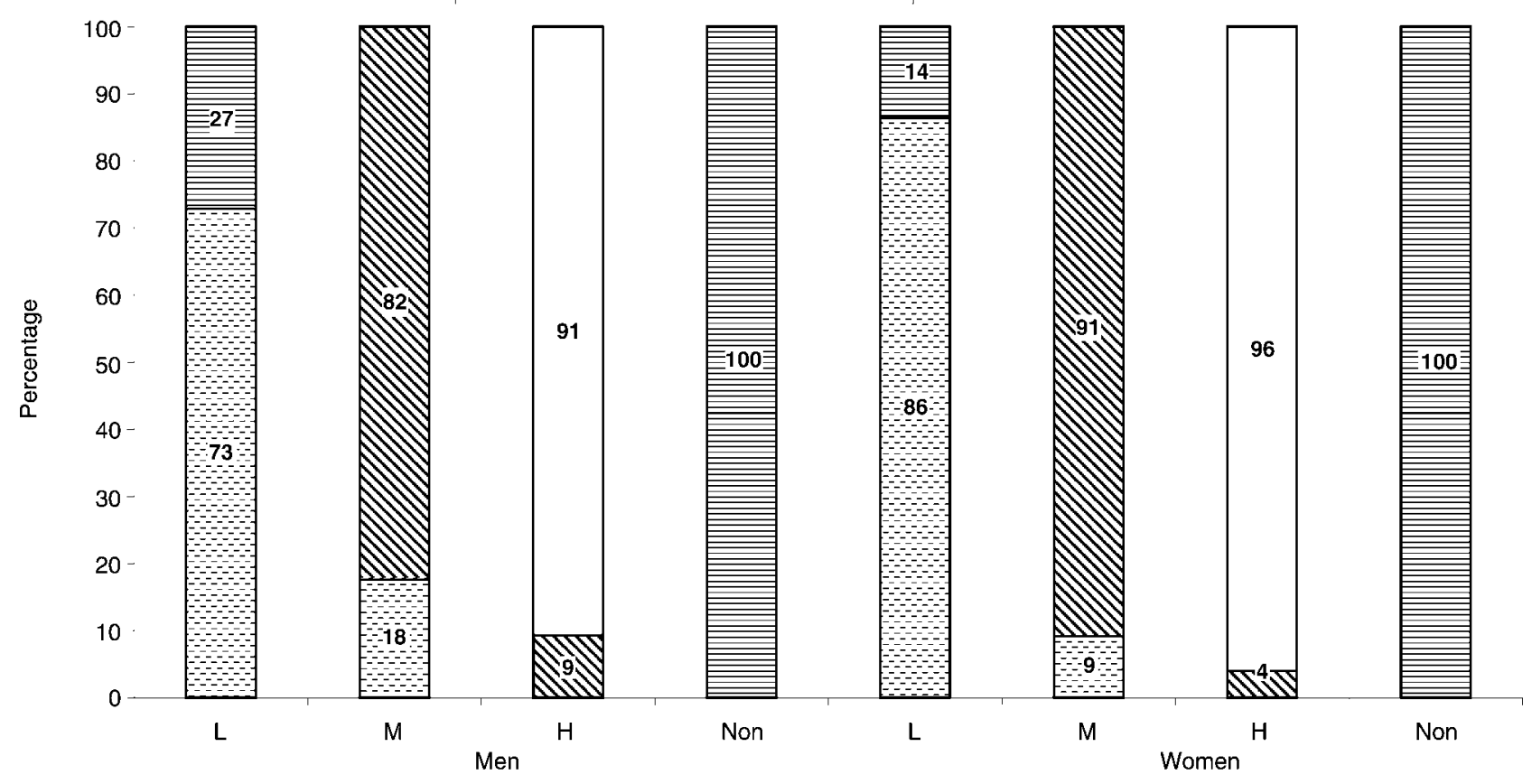

Classification of individuals as low, medium, high and non-consumers of fruit including composite foods in estimates of intake

Fig. 2 Percentage of individuals misclassified as low, medium, high and non-consumers of fruit if composite foods are excluded from estimates of intake 


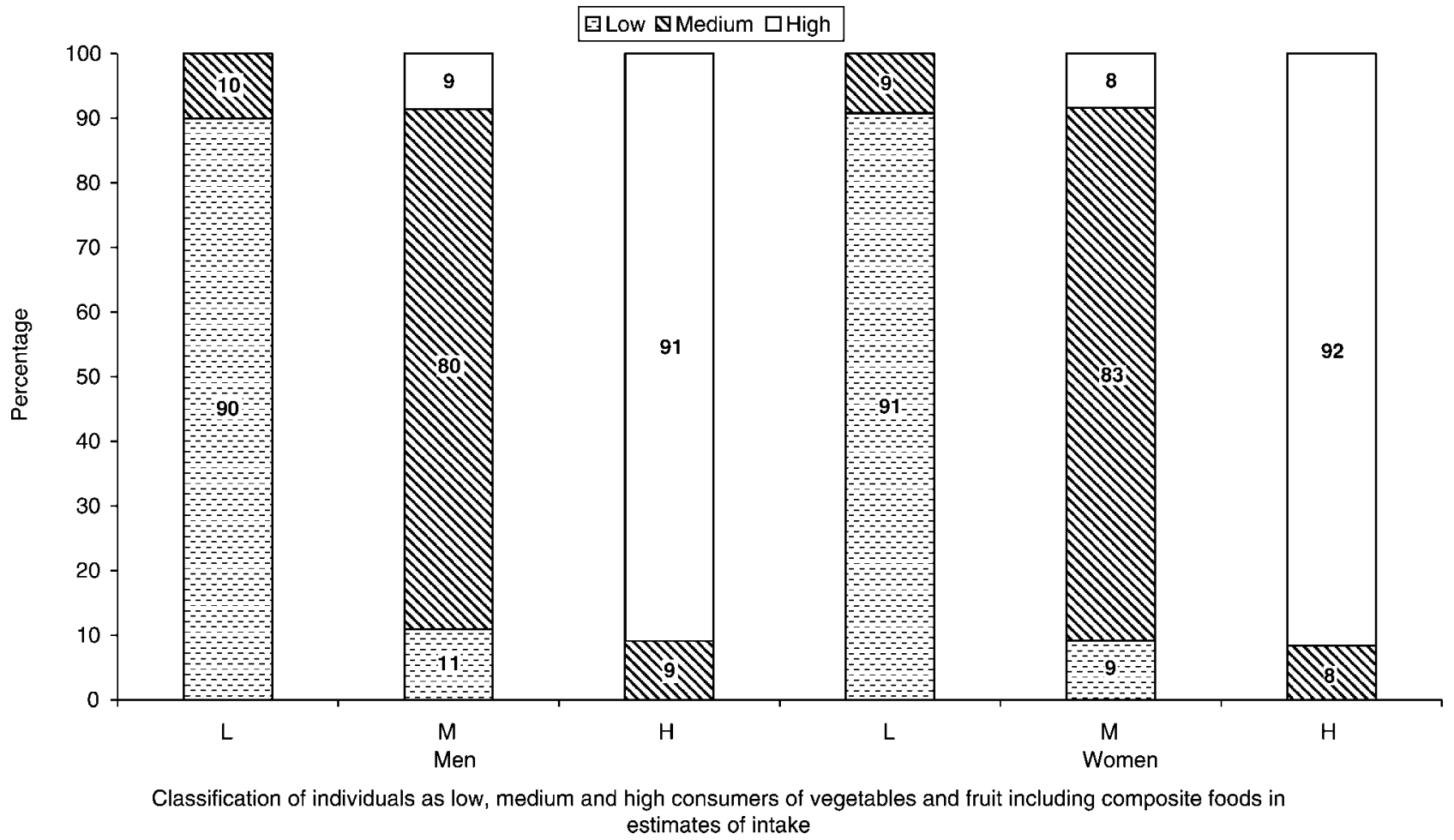

Fig. 3 Percentage of individuals misclassified as low, medium and high consumers of vegetables and fruit if composite foods are excluded from estimates of intake

Table 8 Percentage of individuals in different population groups complying with current dietary recommendations for vegetables and fruit, including and excluding vegetables and fruit from composite foods (CF)

\begin{tabular}{|c|c|c|c|c|c|c|}
\hline & \multicolumn{6}{|c|}{ Percentage of individuals } \\
\hline & \multicolumn{2}{|c|}{$\begin{array}{l}3 \text { servings of } \\
\text { vegetables per day }\end{array}$} & \multicolumn{2}{|c|}{$\begin{array}{l}\geq 2 \text { servings } \\
\text { of fruit per day }\end{array}$} & \multicolumn{2}{|c|}{$\begin{array}{c}\geq 5 \text { servings } \\
\text { of vegetables } \\
\text { and fruit per day } \dagger\end{array}$} \\
\hline & Including CF & Excluding CF & Including CF & Excluding CF & Including CF & Excluding CF \\
\hline \multicolumn{7}{|l|}{ Men } \\
\hline $18-35$ years & 9.0 & 3.2 & 26.9 & 26.9 & 17.4 & 13.0 \\
\hline $36-50$ years & 11.9 & 5.5 & 34.3 & 33.1 & 25.4 & 15.7 \\
\hline $51-64$ years & 9.8 & 5.2 & 32.4 & 30.1 & 21.4 & 16.8 \\
\hline Total & 10.3 & 4.5 & 31.0 & 29.9 & 21.3 & 15.0 \\
\hline \multicolumn{7}{|l|}{ Women } \\
\hline $18-35$ years & 4.1 & 1.1 & 26.4 & 26.4 & 12.6 & 7.4 \\
\hline $36-50$ years & 7.0 & 3.1 & 34.6 & 31.5 & 19.9 & 14.3 \\
\hline $51-64$ years & 6.8 & 1.9 & 40.1 & 39.5 & 27.2 & 19.1 \\
\hline Total & 5.9 & 2.1 & 32.8 & 31.4 & 18.8 & 12.8 \\
\hline \multicolumn{7}{|l|}{ Social class } \\
\hline Professional, managerial \& technical & 9.3 & 3.3 & 41.9 & 40.6 & 27.1 & 18.2 \\
\hline Non-manual \& skilled manual & 5.9 & 1.6 & 29.6 & 28.9 & 16.6 & 11.1 \\
\hline Semi-skilled \& unskilled manual & 9.2 & 4.6 & 23.8 & 22.2 & 15.7 & 11.5 \\
\hline Unskilled & 5.1 & 3.2 & 20.4 & 18.5 & 12.5 & 9.7 \\
\hline \multicolumn{7}{|l|}{ Education level attained } \\
\hline Primary & 5.9 & 2.1 & 20.8 & 19.7 & 13.5 & 11.1 \\
\hline Intermediate & 7.4 & 4.6 & 22.3 & 21.3 & 14.5 & 9.9 \\
\hline Secondary & 8.6 & 4.7 & 36.1 & 34.5 & 21.6 & 16.1 \\
\hline Tertiary & 9.6 & 2.7 & 41.3 & 40.0 & 26.2 & 16.8 \\
\hline \multicolumn{7}{|l|}{ Smoking habits } \\
\hline Current smoker & 23.6 & 24.4 & 18.1 & 17.9 & 14.8 & 15.3 \\
\hline Ex-smoker & 35.5 & 40.0 & 29.5 & 29.7 & 30.3 & 29.6 \\
\hline Non-smoker & 40.9 & 35.6 & 52.4 & 52.4 & 55.0 & 55.0 \\
\hline
\end{tabular}

1 serving $=80 \mathrm{~g}$.

$\dagger$ Equivalent to $\geq 400 \mathrm{~g} \mathrm{day}^{-1}$ vegetable and fruit intake. 
Table 9 Mean contribution of vegetables, fruit and potatoes from all sources (including composite foods (CF)) and from CF alone to mean daily nutrient intake

\begin{tabular}{|c|c|c|c|c|c|c|}
\hline \multirow[b]{3}{*}{ Nutrient } & \multicolumn{6}{|c|}{ Mean contribution (\%) } \\
\hline & \multicolumn{2}{|c|}{ Vegetables } & \multicolumn{2}{|l|}{ Fruit } & \multicolumn{2}{|c|}{ Potatoes } \\
\hline & All sources & CF & All sources & CF & All sources & CF \\
\hline Protein & 3.3 & 0.7 & 0.9 & 0.0 & 6.0 & 0.9 \\
\hline Fat & 2.1 & 0.9 & 0.3 & 0.0 & 8.3 & 1.6 \\
\hline Carbohydrate & 3.3 & 0.8 & 5.4 & 0.2 & 18.1 & 2.5 \\
\hline Energy & 2.7 & 0.8 & 2.7 & 0.1 & 11.8 & 1.8 \\
\hline Total sugars & 5.5 & 1.4 & 13.6 & 0.4 & 2.4 & 0.3 \\
\hline Starch & 2.0 & 0.4 & 0.2 & 0.0 & 27.9 & 3.8 \\
\hline Fibre (Southgate) & 16.9 & 3.4 & 5.5 & 0.3 & 20.5 & 2.9 \\
\hline Fibre (Englyst) & 19.0 & 3.9 & 7.7 & 0.4 & 23.5 & 3.3 \\
\hline Potassium & 6.7 & 2.1 & 2.2 & 0.2 & 25.4 & 3.5 \\
\hline Calcium & 4.2 & 0.9 & 2.0 & 0.1 & 2.3 & 0.4 \\
\hline Magnesium & 5.4 & 1.2 & 4.2 & 0.1 & 14.3 & 2.0 \\
\hline Phosphorus & 4.4 & 1.0 & 1.4 & 0.0 & 7.4 & 1.0 \\
\hline Iron & 7.5 & 1.5 & 2.0 & 0.1 & 10.3 & 1.3 \\
\hline Copper & 3.8 & 1.4 & 11.3 & 0.2 & 16.9 & 2.2 \\
\hline Zinc & 3.8 & 0.9 & 0.9 & 0.0 & 6.6 & 1.0 \\
\hline Retinol & 0.2 & 0.1 & 0.0 & 0.0 & 1.6 & 0.5 \\
\hline Carotene & 63.0 & 11.0 & 1.7 & 0.1 & 0.4 & 0.3 \\
\hline Total vitamin A & 32.1 & 5.5 & 1.2 & 0.0 & 0.9 & 0.2 \\
\hline Vitamin D & 0.0 & 0.0 & 0.0 & 0.0 & 2.0 & 0.4 \\
\hline Vitamin E & 12.7 & 2.8 & 5.0 & 0.2 & 14.8 & 1.8 \\
\hline Thiamin & 6.6 & 1.6 & 3.5 & 0.1 & 19.4 & 2.6 \\
\hline Riboflavin & 2.8 & 0.8 & 1.9 & 0.1 & 2.4 & 0.4 \\
\hline $\begin{array}{l}\text { Total niacin } \\
\text { equivalents }\end{array}$ & 7.5 & 0.7 & 1.4 & 0.0 & 6.6 & 0.9 \\
\hline Vitamin $B_{6}$ & 5.4 & 1.7 & 4.2 & 0.1 & 26.5 & 3.6 \\
\hline Vitamin $B_{12}$ & 0.0 & 0.0 & 0.0 & 0.0 & 0.1 & 0.1 \\
\hline Folate & 10.6 & 3.3 & 5.0 & 0.1 & 18.5 & 2.5 \\
\hline Pantothenate & 5.5 & 1.7 & 2.3 & 0.1 & 12.9 & 1.9 \\
\hline Biotin & 3.9 & 1.0 & 3.6 & 0.1 & 2.1 & 0.3 \\
\hline Vitamin C & 23.7 & 6.5 & 25.0 & 0.6 & 27.0 & 3.9 \\
\hline
\end{tabular}

potatoes. Overall, potatoes contributed about $8 \%$ of total fat intake and over $70 \%$ of fat from potatoes came from chipped, fried and roasted potatoes.

Fruit contributed $<3 \%$ to mean daily intakes of total energy and contributed about $14 \%$ of mean daily total sugar, $25 \%$ of vitamin C and 11\% of copper (Table 9). Fruit juice and citrus fruits contributed most significantly to the intake of vitamin $\mathrm{C}$ from fruit.

The effect of excluding composite foods from estimates of intake on calculation of the contribution of vegetables, fruit and potatoes to each nutrient is reported in Table 9.

In Table 10, the intakes of fruit and vegetables obtained from this analysis are compared with intakes from other European countries. Mean intake of total vegetables (excluding potatoes) and fruit was much lower in Ireland than in Spain ${ }^{46}$ and Italy ${ }^{47}$ but comparable to that in other countries. Intake of potatoes was similar to that in the $\mathrm{UK}^{22}$ but higher than in other European countries for which data are reported ${ }^{20,21,42-47}$

\section{Discussion}

The current analysis indicates that intakes of vegetables and fruit in Ireland are roughly similar to those in most Northern European countries but considerably lower than in Spain and Italy. The differences in intakes are most striking for fruit, with consumption being almost three times higher in Spain than in Ireland. Potato consumption in Ireland is comparable with that in the UK but almost twice the intake reported in other European countries. There is evidence that potato consumption in Ireland has decreased over the last decade, with the contribution of potato to percentage of energy decreasing from $12-14 \%{ }^{42}$ to $11-13 \%$ in the current analysis. Potatoes are generally not included with vegetables in dietary guidelines for vegetable consumption although the rationale for their exclusion is not clear. There is inconsistency and sometimes lack of clarity as to whether or not potatoes should be counted in meeting current recommendations ${ }^{2,18}$ for vegetables and fruit.

The main contributions made by vegetables to nutrient intakes were for fibre, carotene (and hence vitamin A), folate and vitamins $\mathrm{C}$ and $\mathrm{E}$. Fruit contributed significantly only to sugar, copper and vitamin C. Although the health benefits of high vegetable and fruit consumption are evident, it has not yet been elucidated whether these benefits are associated with their content of essential nutrients or with other components (e.g. phytochemicals), or both. Potatoes made a significant contribution to a wide range of nutrients in the diet, accounting for over $10 \%$ of the population mean daily intakes of energy, carbohydrate, dietary fibre, potassium, magnesium, iron, copper, vitamins $\mathrm{B}_{6}, \mathrm{C}$ and $\mathrm{E}$, thiamin, folate and pantothenate. The exclusion of vegetables and fruit from composite foods from estimates of intakes results in underestimation of the contributions of vegetables and fruit to total nutrient intakes.

Bingham et al. ${ }^{48}$ have previously concluded that a 7-day estimated food diary (as used in the current survey) can be used to measure habitual food intake. It is presumed therefore that the current estimates represent habitual individual intakes of vegetables and fruit. The current survey, as with all dietary surveys, had evidence of misreporting of energy intakes ${ }^{49}$. Previous studies have indicated that estimates of vegetable and fruit intakes were not significantly different between misreporters and good reporters ${ }^{49}$, and a recent study reported that vegetables and fruit were consumed with the same frequency in both misreporters and good reporters ${ }^{50}$. The impact of misreporting on estimates of vegetable and fruit intake was assessed in the current analysis by using Goldberg's cut-off of EI/BMR $<1.05^{41}$. Excluding the $20 \%$ of individuals who had EI/BMR $<1.05$ resulted in a small increase in the mean intake of $3.5 \%$ for total vegetables (excluding potatoes), $5.4 \%$ for fruit and $7.5 \%$ for potatoes. As these effects were relatively small and as previous studies have indicated that vegetables and fruit are unlikely to be misreported, the results presented in the current paper include these individuals.

Vegetables and fruits consumed as individual portions and as composite foods containing vegetables were 
Table 10 Mean daily intakes of vegetables and fruit in Ireland, compared with other European countries

\begin{tabular}{|c|c|c|c|c|c|c|c|c|}
\hline \multirow[b]{2}{*}{ Country, study and reference } & \multirow[b]{2}{*}{ Method } & \multirow[b]{2}{*}{$\begin{array}{c}\text { Age } \\
\text { (years) }\end{array}$} & \multicolumn{6}{|c|}{ Mean intake $\left(\mathrm{g} \mathrm{day}^{-1}\right)$} \\
\hline & & & \multicolumn{2}{|c|}{$\begin{array}{l}\text { Total vegetables } \\
\text { (excluding } \\
\text { potatoes) }\end{array}$} & \multicolumn{2}{|c|}{ Potatoes } & \multicolumn{2}{|c|}{ Total fruit } \\
\hline \multirow{7}{*}{$\begin{array}{l}\text { Ireland } \\
\text { Irish Universities Nutrition Alliance, } \\
2001 \text { (this study) }\end{array}$} & \multirow{7}{*}{ 7-day food record } & \multirow{7}{*}{$18-64$} & \multicolumn{6}{|c|}{ Excluding composite foods } \\
\hline & & & Men & 112 & Men & 277 & Men & 126 \\
\hline & & & Women & 96 & Women & 148 & Women & 134 \\
\hline & & & \multicolumn{5}{|c|}{ Including composite foods } & 130 \\
\hline & & & Men & 149 & Men & 296 & Men & 133 \\
\hline & & & Women & 132 & Women & 163 & Women & 140 \\
\hline & & & All & 140 & All & 227 & All & 136 \\
\hline \multicolumn{9}{|l|}{ Ireland } \\
\hline Lee and Cunningham, $1990^{42}$ & 7-day diet history & $18+$ & Men & 119 & Men & 340 & Men & 93 \\
\hline & & & Women & 89 & Women & 190 & Women & 128 \\
\hline $\begin{array}{l}\text { UK } \\
\text { Gregory et al., } 1990^{22}\end{array}$ & 7-day weighed record & $16-64$ & All & 152 & All & 221 & All & 72 \\
\hline \multicolumn{9}{|l|}{ Belgium } \\
\hline De Hennauw and De Backer, $1999^{20}$ & 24-hour estimated & $25-74$ & Men & 139 & & & Men & 207 \\
\hline \multicolumn{8}{|l|}{ France } & 205 \\
\hline \multirow[t]{2}{*}{ Volatier and Verger, $1999^{21}$} & 7-day dietary history & $>18$ & Men & 93 & & & Men & 189 \\
\hline & questionnaire & & Women & 109 & & & Women & 184 \\
\hline \multicolumn{9}{|l|}{ Denmark } \\
\hline \multirow[t]{2}{*}{ Haraldsdóttir, $1999^{43}$} & 7-day estimated food & $15-80$ & Men & 128 & Men & 128 & Men & 152 \\
\hline & record & & Women & 103 & Women & 103 & Women & 179 \\
\hline \multicolumn{9}{|l|}{ Finland } \\
\hline \multirow[t]{2}{*}{ Anttolainen et al., $1998^{44}$} & 24-hour estimated food & $25-64$ & Men & 119 & Men & 143 & Men & 173 \\
\hline & record & & Women & 122 & Women & 84 & Women & 214 \\
\hline \multirow{4}{*}{$\begin{array}{l}\text { Holland } \\
\text { Zoo eet Netherland, } 1998^{45}\end{array}$} & & & & & & & & \\
\hline & 2-day record & $19-65+$ & Men & 144 & Men & 147 & Men & 107 \\
\hline & & & Women & 137 & Women & 107 & Women & 125 \\
\hline & & & All & 123 & & 114 & & 105 \\
\hline \multirow{3}{*}{$\begin{array}{l}\text { Spain } \\
\text { Agudo et al., } 1999^{46}\end{array}$} & & & & & & & & \\
\hline & diet history (previous year) & $29-69$ & Men & 274 & & & Men & 348 \\
\hline & & & Women & 244 & & & Women & 349 \\
\hline \multirow{2}{*}{\multicolumn{2}{|c|}{$\begin{array}{l}\text { Italy } \\
\text { Turrini et al., } 1999^{47}\end{array}$}} & & & \multirow{2}{*}{\multicolumn{5}{|c|}{$433 \mathrm{~g}$ of vegetables and fruit per day }} \\
\hline & & $18-60$ & All & & & & & \\
\hline
\end{tabular}

quantified mainly using a photographic food atlas ${ }^{29}$, and the use of in-house or average portion size data from $\mathrm{MAFF}^{30}$ was kept to a minimum. The disadvantage of using average portion sizes is that a single fixed weight is assigned to each food item and overuse leads to overstandardisation of portions, thus attenuating efforts to collect truly individual data. The vegetable and fruit components of composite foods were quantified using recipe information collected during the course of the survey; recipe information from McCance \& Widdowson's The Composition of Foods, fifth edition and manufacturers' ingredient information was used when recipe information was not available.

Information on serving sizes for vegetables and fruit is very limited in the literature. Serving size has important implications when estimating intakes (e.g. in foodfrequency questionnaires (FFQs)) and in aiding individuals when interpreting dietary advice regarding vegetable and fruit intakes. An average serving size of $80 \mathrm{~g}$ is commonly used for dietary guidance ${ }^{2,25}$. This $80 \mathrm{~g}$ serving size is an interpretation of the World Health Organization's recommendation of $400 \mathrm{~g} \mathrm{day}^{-1}$ of vegetables and fruit as
5 servings ( $80 \mathrm{~g}$ ) a day ${ }^{2}$. Therefore its foundation was not based on any formal analysis of suitable data to estimate frequency of consumption and portion size correctly. In the absence of another definition of serving size, $80 \mathrm{~g}$ has been used to define serving size in this paper when estimating compliance with current recommendations of vegetable and fruit intake.

In this study, an average serving size of individually consumed vegetables was estimated to be $105 \mathrm{~g}$ (average portion consumed in composite foods was $75 \mathrm{~g}$ ), while an average serving of individual fruit consumed was $169 \mathrm{~g}$ (average portion of fruit consumed in composite foods was $39 \mathrm{~g}$ ). While the method used in this survey for quantification of vegetable and fruit intakes (primarily the photographic atlas) has limitations in its ability to define the distribution of serving size, it is clear that the use of $80 \mathrm{~g}$ as a reference value for average serving sizes is a sizeable underestimate for vegetables, and particularly for fruit, consumed as discrete portions.

While the 7-day food diary provided a sufficient level of recipe information to permit the disaggregation of vegetables and fruit consumed in composite foods, other 
methods of dietary assessment (e.g. FFQs) present serious limitations when it comes to estimating the intake of vegetables and fruit from composite foods, as this level of disaggregation is not possible. There are no databases available that provide the content of individual foods in composite foods, so it was necessary to develop such a database in the course of this analysis. The development of such databases has important applications especially in the field of nutritional epidemiology, to allow more accurate assessment of vegetable and fruit intakes. Improved accuracy in estimating food intakes is crucial to improve the detection of real diet-disease relationships in populations.

Composite foods contributed on average $37 \mathrm{~g} \mathrm{day}^{-1}$ of vegetables $(26 \%$ of mean vegetable intake in the population), $6 \mathrm{~g} \mathrm{day}^{-1}$ (4\%) of fruit and $17 \mathrm{~g} \mathrm{day}^{-1}(7 \%)$ of potatoes. The contribution of composite foods was most significant for the 'other vegetables' category ( $24 \mathrm{~g} \mathrm{day}^{-1}$ or $33 \%$ of the total intake of 'other vegetables' in the population). The predominant vegetables in this category were mushrooms, onions and peppers. This indicates the importance of measuring vegetables that are consumed individually as small amounts in composite foods, but which contribute significantly to total vegetable intakes. These findings highlight the potential for underestimation of mean intakes of fruit and particularly vegetables in population groups if composite foods are excluded. Other investigators have also highlighted the importance of considering the contribution made by composite foods to fruit and vegetable intakes ${ }^{23-25,51}$. Krebs-Smith et al. ${ }^{51}$ examined vegetable and fruit intakes in American adults, including vegetables and fruit disaggregated from composite foods, and found that $29 \%$ of vegetables and $11 \%$ of fruit came from composite foods, similar to the proportions found in the current analysis.

In relation to individuals, composite foods contributed on average $27 \%$ (P95 68\%) of their total vegetable intake, $12 \%$ (P95 100\%) of fruit intake and 9\% (P95 46\%) of potato intake. There was a considerable variation between individuals in the mean daily intake of vegetables and fruit from composite foods. For example, for mean daily vegetable intake (excluding potatoes) P5 and P95 were 0 and $106 \mathrm{~g}$, respectively, while for fruit intakes P5 and P95 were 0 and $27 \mathrm{~g}$, respectively. Therefore estimates excluding vegetables and fruit from composite foods would result in the misclassification of individuals into thirds of intake. For example, an examination of thirds of intake of vegetables in this analysis revealed that, when vegetables from composite foods were excluded, $25 \%$ of men and $26 \%$ of women were misclassified as being in the lowest third of intake, and 21\% and 23\% of men and women, respectively, were misclassified as being in the highest third of intake for vegetables. Similarly, when fruit from composite foods was excluded, $27 \%$ of men and $14 \%$ of women were misclassified as non-consumers and $9 \%$ of men and $4 \%$ of women were misclassified as being in the highest third of intake for fruit.

Excluding composite foods from estimates of intake of vegetables introduces an unequal bias to estimates of intake in different population groups. Intakes of vegetables from composite foods were similar between men and women and between different age groups. However, significant differences in intakes of vegetables from composite foods across categories of social class and education level attained may introduce bias in the estimates of intake in these population groups when composite foods are excluded. This is particularly apparent in those individuals with tertiary education and professional, managerial and technical workers who are consuming more vegetables from composite foods. It is important therefore to pay particular attention to composite foods when estimating vegetable intakes in these groups. Health promotion strategies could also be developed to increase vegetable consumption through the promotion of vegetable-containing composite foods in certain population groups.

Excluding composite foods from the estimation of intakes can also underestimate the level of compliance with dietary guidelines as well as exposure to food chemicals such as pesticides, of which vegetables and fruit would be an important source. This study shows that compliance with guidelines for intake of vegetables and fruit is low. Only 20\% of Irish adults achieved the recommendation for an intake of $\geq 400 \mathrm{~g}$ ( 5 or more $80 \mathrm{~g}$ servings) of vegetables and fruit per day ${ }^{19}$. When fruit and vegetables from composite foods were excluded, less than $15 \%$ of men and $13 \%$ of women achieved this recommendation. When evaluated against US guidelines ${ }^{17}$ only $10 \%$ ( $5 \%$ excluding composite foods) of men and $\sim 6 \%$ ( $2 \%$ excluding composite foods) of women achieved the American recommendations of 3 servings of vegetables a day. When composite foods were included in estimates of fruit intakes, $31 \%$ of men and $\sim 33 \%$ of women achieved recommendations for 2 servings of fruit per day. Compliance with current recommendations for fruit was largely unaffected when composite foods were excluded from estimates of intakes because of the small contribution that composite foods made to total fruit intakes.

The current analysis found a significant pattern of decreasing compliance with recommendations for vegetable and fruit intake in men and women with decreasing level of educational attainment and social class, when composite foods were both included and excluded. Current smokers also had a significantly lower level of compliance compared with non-smokers. Previous investigators have reported lower intakes of vegetables and fruit in people with a low level of education ${ }^{52}$, in low socioeconomic groups ${ }^{53,54}$ and in those who smoke ${ }^{55}$. This trend of decreasing vegetable and fruit consumption with decreasing level of educational attainment and social class 
indicates that the cost to the consumer of purchasing vegetables and fruit may be an important barrier to increasing vegetable and fruit consumption in Ireland. Other factors such as lack of knowledge or understanding of dietary guidelines for achieving health may also be important.

\section{Conclusion}

Intakes of vegetables and fruit are low compared with current dietary recommendations, particularly in those of lower levels of educational attainment and social class. Composite foods are an important source of vegetables (less importantly of fruit) and should be included when estimating vegetable intakes. Failure to do so may result in bias in estimates of intake and of compliance with dietary guidelines for population groups, as well as misclassification of individuals by level of intake.

\section{Acknowledgements}

This work was supported by funding made available by the Irish Government under the National Development Plan 2000-2006.

\section{References}

1 Committee on Medical Aspects of Food Policy. Nutritional Aspects of the Development of Cancer. Report of the Working Group on Diet and Cancer. Report on Health and Social Subjects No. 48. London: HMSO, 1998.

2 American Institute for Cancer Research (AICR). Food, Nutrition and the Prevention of Cancer: A Global Perspective. Washington, DC: AICR, 1997.

3 Klerk M, Jansen MCJF, van't Veer P, Kok FJ. Fruits and Vegetables in Chronic Disease Prevention. Wageningen, The Netherlands: Division of Human Nutrition \& Epidemiology, Wageningen Agricultural University, 1997.

4 Block G, Patterson B, Subar A. Fruit, vegetables and cancer prevention: a review of the epidemiological evidence. Nutrition and Cancer 1992; 18: 1-29.

5 Steinmetz KA, Potter JD. Vegetables, fruit and cancer. I. Epidemiology. Cancer Causes \& Control 1991; 2: 325-57.

6 Eichhlozer M, Lüthy J, Gutzwiller F, Stähelin HB. The role of folate, antioxidant vitamins and other constituents in fruit and vegetables in the prevention of cardiovascular disease: the epidemiological evidence. International Journal for Vitamin and Nutrition Research 2001; 71(1): 5-17.

7 Liu S, Lee I, Ajani U, Coel SR, Buring JE, Manson JE. Intake of vegetables rich in carotenoids and risk of coronary heart disease in men: The Physicians Health Study. International Journal of Epidemiology 2001; 30: 130-5.

8 Ness AR, Powles JW. Fruit and vegetables, and cardiovascular disease: a review. International Journal of Epidemiology 1997; 26(1): 1-13.

9 Rimm EB, Ascerio A, Giovannucci E, Spiegelman D, Stampfer MJ, Willett WC. Vegetables, fruit and cereal fiber intake and risk of coronary heart disease among men. Journal of the American Medical Association 1996; 275(6): $447-51$.

10 Joshipura KJ, Ascherio A, Manson JE, Stampfer MJ, Rimm EB, Speizer FE, et al. Fruit and vegetable intake in relation to risk of ischemic stroke. Journal of the American Medical Association 1999; 282(13): 1233-9.

11 Gillman MW, Cupples LA, Gagnon D, Posner BM, Ellison C, Castelli WP, et al. Protective effect of fruits and vegetables on development of stroke in men. Journal of the American Medical Association 1995; 273(14): 1113-7.

12 Williams DEM, Wareham NJ, Cox BD, Byrne CD, Hales N, Day NE. Frequent salad vegetable consumption is associated with a reduction in the risk of diabetes mellitus. Journal of Clinical Epidemiology 1999; 52(4): 329-35.

13 New SA, Robins SP, Campbell MK, Martin JC, Garton MJ, Bolton-Smith C, et al. Dietary influence on bone mass and bone metabolism: further evidence of a positive link between fruit and vegetable consumption and bone health? American Journal of Clinical Nutrition 2000; 71: 142-51.

14 Tucker LJ, Hamman MT, Chen H, Cupples LA, Wilson PWF, Douglas PK. Potassium, magnesium and fruit and vegetable intakes are associated with greater bone mineral density in elderly men and women. American Journal of Clinical Nutrition 1999; 69: 727-36.

15 Steinmetz KA, Potter JD. Vegetables, fruit and cancer prevention: a review. Journal of the American Dietetic Association 1996; 96: 1027-39.

16 La Vecchia C, Tavani A. Fruit and vegetables, and human cancer. European Journal of Cancer Prevention 1998; 7: 3-8.

17 US Department of Agriculture (USDA). Dietary Guidelines for Americans 2000 [online]. Available at http://www. health.gov/dietaryguidelines/. Washington, DC: USDA, 2000 .

18 Nutrition Advisory Group. Recommendations for a Food and Nutrition Policy for Ireland. Dublin: Government of Ireland, 2000.

19 World Health Organization (WHO)/Food and Agriculture Organization. Diet, Nutrition and the Prevention of Chronic Diseases. WHO Technical Report Series No. 916. Geneva: WHO, 2003.

20 De Hennauw S, De Backer G. Nutrient and food intakes in selected subgroups of Belgian adults. British Journal of Nutrition 1999; 81(Suppl. 2): S37-42.

21 Volatier J, Verger P. Recent national French food and nutrient intake data. British Journal of Nutrition 1999; 81(Suppl. 2): S57-9.

22 Gregory J, Foster K, Tyler H, Wiseman M. The Dietary and Nutritional Survey of British Adults. London: HMSO, 1990.

23 Krebs-Smith SM, Kantor LS. Choose a variety of fruits and vegetables daily: understanding the complexities. Journal of Nutrition 2001; 131: 487S-501S.

24 Cleveland LE, Cook AC, Krebs-Smith SM, Friday J. Method for assessing food intakes in terms of servings based on food guidance. American Journal of Clinical Nutrition 1997; 65(Suppl.): 1254S-63S.

25 Williams C. Healthy eating: clarifying advice about fruit and vegetables. British Medical Journal 1995; 310: 1453-5.

26 Irish Universities Nutrition Alliance (IUNA). North/South Ireland Food Consumption Survey Database. Dubin: University College Cork, Trinity College Dublin, University of Ulster at Coleraine, 2001.

27 Kiely M, Flynn A, Harrington KE, Robson PR, Cran G. Sampling description and procedures used to conduct the North/South Ireland Food Consumption Survey. Public Health Nutrition 2001; 4(5A): 1029-35.

28 Harrington KE, Robson PJ, Kiely M, Livingstone MBE, Lambe J, Gibney MJ. The North/South Ireland Food Consumption Survey: survey design and methodology. Public Health Nutrition 2001; 4(5A): 1037-42.

29 Robson PJ, Livingstone MBE. A photographic atlas of food portion sizes, 1997 [unpublished].

30 Ministry of Agriculture, Fisheries and Food. Food Portion Sizes. London: HMSO, 1997. 
31 Holland B, Welch AA, Unwin ID, Buss DH, Paul AA, Southgate DAT. McCance \& Widdowson's The Composition of Foods, 5th ed. Royal Society of Chemistry and Ministry of Agriculture, Fisheries and Food. London: HMSO, 1995.

32 Holland B, Unwin ID, Buss DH. Cereals and Cereal Products. Third Supplement to McCance \& Widdowson's The Composition of Foods, 4th ed. Royal Society of Chemistry and Ministry of Agriculture, Fisheries and Food. London: HMSO, 1988.

33 Holland B, Unwin ID, Buss DH. Milk Products and Eggs. Fourth Supplement to McCance \& Widdowson's The Composition of Foods, 4th ed. Royal Society of Chemistry and Ministry of Agriculture, Fisheries and Food. London: HMSO, 1989.

34 Holland B, Unwin ID, Buss DH. Vegetables, Herbs and Spices. Fifth Supplement to McCance \& Widdowson's The Composition of Foods, 4th ed. Royal Society of Chemistry and Ministry of Agriculture, Fisheries and Food. London: HMSO, 1991.

35 Holland B, Unwin ID, Buss DH. Fruit and Nuts. First Supplement to McCance \& Widdowson's The Composition of Foods, 5th ed. Royal Society of Chemistry and Ministry of Agriculture, Fisheries and Food. London: HMSO, 1992.

36 Holland B, Welch AA, Buss DH. Vegetable Dishes. Second Supplement to McCance \& Widdowson's The Composition of Foods, 5th ed. Royal Society of Chemistry and Ministry of Agriculture, Fisheries and Food. London: HMSO, 1996.

37 Holland B, Brown J, Buss DH. Fish and Fish Products. Third Supplement to McCance \& Widdowson's The Composition of Foods, 5th ed. Royal Society of Chemistry and Ministry of Agriculture, Fisheries and Food. London: HMSO, 1993.

38 Chan W, Brown J, Buss DH. Miscellaneous Foods. Fourth Supplement to McCance \& Widdowson's The Composition of Foods, 5th ed. Royal Society of Chemistry and Ministry of Agriculture, Fisheries and Food. London: HMSO, 1994.

39 Chan W, Brown J, Lee SM, Buss DH. Meat, Poultry and Game. Supplement to McCance \& Widdowson's The Composition of Foods. Royal Society of Chemistry and Ministry of Agriculture, Fisheries and Food. London: HMSO, 1995.

40 Chan W, Brown J, Church SM, Buss DH. Meat Products and Dishes. Supplement to McCance \& Widdowson's The Composition of Foods. Royal Society of Chemistry and Ministry of Agriculture, Fisheries and Food. London: HMSO, 1996.

41 Goldberg GR, Black AE, Jebb SA, Cole TJ, Murgatroyd PR, Howard WA, et al. Critical evaluation of energy intake data using fundamental principles of energy physiology: 1 Derivation of cut-off limits to identify under-recording. European Journal of Clinical Nutrition 1991; 45: 569-81.

42 Lee P, Cunningham K. The Irish National Nutrition Survey. Dublin: Irish Nutrition and Dietetic Institute, 1990.

43 Haraldsdóttir J. Dietary guidelines and patterns of intake in
Denmark. British Journal of Nutrition 1999; 81(Suppl. 2): S43-8.

44 Anttolainen M, Javanainen J, Kaatinen P, Lahti-Koski M, Lauronen J, Männisto S, et al. The 1997 Dietary Survey of Finnish Adults. Helsinki: National Public Health Institute, 1998.

45 Zoo eet Nederland. Results of the 3rd Dutch National Food Consumption Survey. Voedingscentrum Den Haag: Zoo eet Nederland, 1998.

46 Agudo A, Amiano P, Barcos A, Barricarte A, Beguiristain JM, Chirlaque MD, et al. (EPIC Group of Spain). Dietary intake of vegetables and fruits among adults in five regions of Spain. European Journal of Clinical Nutrition 1999; 53: 174-80.

47 Turrini A, Leclercq C, D'Amicis A. Patterns of food and nutrient intakes in Italy and their application to the development of food-based dietary guidelines. British Journal of Nutrition 1999; 81(Suppl. 2): S83-9.

48 Bingham SA, Cassidy A, Cole T, Welch A, Runswich S, Black $\mathrm{AE}$, et al. Validation of weighed records and other methods of dietary assessment using the $24 \mathrm{hr}$ urine technique and other biological markers. British Journal of Nutrition 1995; 73: $531-50$.

49 McGowan MJ, Harrington KE, Kiely M, Robson PJ, Livingstone MBE, Gibney MJ. An evaluation of energy intakes and the ratio of energy intake to estimated basal metabolic rate $\left(\mathrm{EI} / \mathrm{BMR}_{\mathrm{est}}\right)$ in the North/South Ireland Food Consumption Survey. Public Health Nutrition 2001; 4(5A): $1043-50$.

50 Lafay L, Mennen L, Basdevant A, Charles MA, Borys JM, Eschwège E, et al. and the FLVS Study Group. Does energy intake underreporting involve all kinds of food or only specific food items? Results from the Fleurbaix Laventie Ville Santé (FLVS) study. International Journal of Obesity and Related Metabolic Disorders 2000; 24: 1500-6.

51 Krebs-Smith SM, Cook A, Subar AF, Cleveland L, Friday J. US adults' fruit and vegetable intakes, 1989 to 1991: a revised baseline for the Healthy People 2000 objective. American Journal of Public Health 1995; 85(12): 1623-9.

52 Roos G, Johansson L, Kasmel A, Klumbiené J, Prättälä R. Disparities in vegetables and fruit consumption: European cases from the north to the south. Public Health Nutrition 2001; 4(1): 35-43.

53 De Irala-Estévez J, Groth M, Johansson L, Oltersdorf U, Prättälä R, Martínez-González MA. A systematic review of socio-economic differences in food habits in Europe: consumption of fruit and vegetables. European Journal of Clinical Nutrition 2000; 54: 706-14.

54 Lindström M, Hanson BS, Wirfält E, Östergren P. Socioeconomic differences in the consumption of vegetables, fruit and fruit juices. The influence of psychosocial factors. European Journal of Public Health 2001; 11(1): 51-9.

55 Birkitt J. Intake of fruits and vegetables in smokers. Public Health Nutrition 1999; 2(2): 217-22. 